\title{
Erratum to: Single-Cell Transcriptomic Characterization of Vertebrate Brain Composition, Development, and Function
}

\author{
Bosiljka Tasic, Boaz P. Levi and Vilas Menon
}

\section{Erratum to:}

Chapter 18 in: A. Celik and M.F. Wernet (eds.), Decoding Neural Circuit Structure and Function, https://doi.org/10.1007/978-3-319-57363-2_18

In the original version of the book, Figure 18.4 has to be updated with the new figure in Chapter 18, which is a belated correction. The erratum chapter and the book have been updated with the change.

The updated online version of this chapter can be found at

https://doi.org/10.1007/978-3-319-57363-2_18 